\title{
NTRK1 Gene Amplification
}

National Cancer Institute

\section{Source}

National Cancer Institute. NTRK1 Gene Amplification. NCI Thesaurus. Code C153062.

A molecular genetic abnormality indicating the presence of multiple copies of the NTRK1 gene. 